\title{
PALEOMAGNETISM AND AGE RELATIONS OF THE ROCKS IN THE MAIN SULPHIDE ORE BELT IN CENTRAL FINLAND
}

\author{
K. J. NEUVONEN, KALEVI KORSMAN, OLAVI KOUVO \\ and JORMA PAAVOLA
}

\begin{abstract}
NEUVONEN, K. J., KORSMAN, K., KOUVO, O. and PAAVOLA, J. 1981: Paleomagnetism and age relations of the rocks in the Main Sulphide Ore Belt in central Finland. Bull. Geol. Soc. Finland 53-2, 109-133.

Paleomagnetic data on the Main Sulphide Ore Belt in Finland are coherent but differ clearly from those obtained on the Archean basement area immediately north of it.

The coherent magnetization in the Belt could have been caused by (i) axial uplift, (ii) a plate suture along the Belt or (iii) a short-time igneous pulse. The last interpretation is accepted since it agrees with the radiometric age data. Thus the paleomagnetic measurements in the area date the same thermal events as do the radiometric $\mathrm{U}-\mathrm{Pb}$ age determinations, and the shape of the APW curve is thereby verified. A paleomagnetic pole determined for dykes intersecting the Archean basement block lies off the accepted APW curve which possibly need to be corrected. The magmatic pulse between $1880-$ $1840 \mathrm{Ma}$ may have been associated with a plate collision or with a deep fluid convection producing the sulphide ore precipitation within the Belt.

K. J. Neuvonen, Dept. of Geology and Mineralogy, University of Turku, SF-20500 Turku 50, Finland

Kalevi Korsman and Olavi Kouvo, Geological Survey of Finland, SF-02150 Espoo 15, Finland.

Jorma Paavola, Geological Survey of Finland, Box 237, SF-70101 Kuopio 10, Finland.
\end{abstract}

\section{Introduction}

Paarma and Marmo (1961) were the first to point out that a large number, if not most, of the ore deposits known in Finland are located in belt about $100 \mathrm{~km}$ wide running in a NW-SE direction from Lake Ladoga to the town of Raahe (Fig. 1). This belt lies parallel to common fault lines in the same area (Härme 1961) and to a deep negative gravimetric anomaly (Honkasalo 1962) bordering the belt on its SW side. Mikkola and Niini $(1966,1968)$ divided the zone into three metallogenic provinces and noticed an abundance of basic (subsilisic) intrusions within the belt associated with the ore bodies. In his discussion on the metallogenic features of Finland. Kahma (1973) refers to this, belt as the "Main Sulphide Ore Belt».
Very little, however, is known, about the geological background of this belt. It is part of the Svecokarelian tectonic province but lies on the boundary with the Archean basement gneiss, which runs roughly subparallel to the northeastern edge of the Belt but is in places more than $100 \mathrm{~km}$ northeast of it. According to Penttilä (1963), the area shows seismic activity. Talvitie (1971) made a detailed study of the seismotectonics of the Kuopio region (Fig. 1), which is cut by fractures and fault lines belonging to the sulphide ore zone. He observed the most pronounced lineaments in directions $0^{\circ}-5^{\circ}, 270^{\circ}-275^{\circ}$, $305^{\circ}$ and $325^{\circ}$. The latter two are roughly. parallel to the Main Sulphide Ore Belt. From seismotectonic interpretation and precise levelling he concluded (op. cit, p. 37) that the 


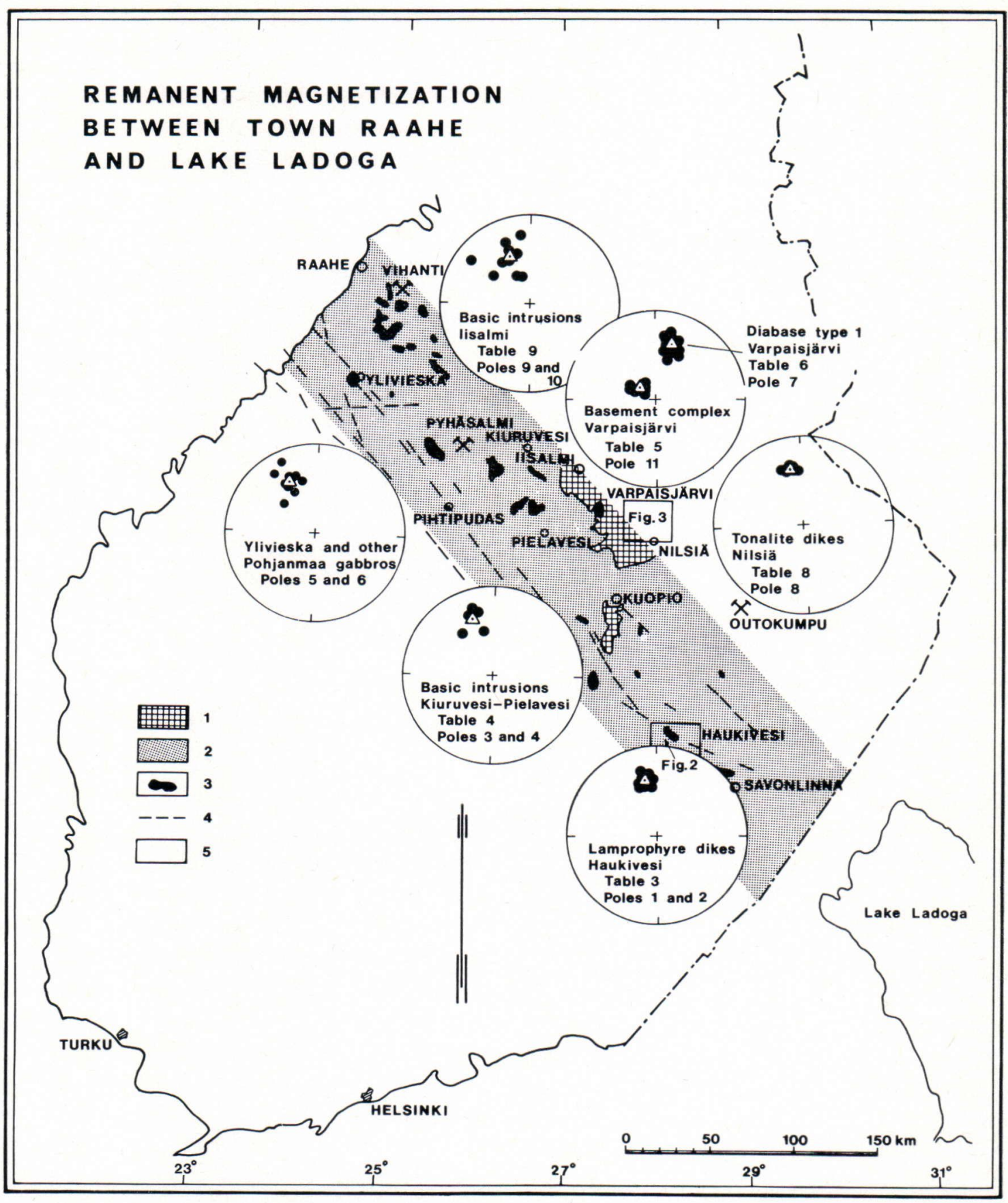

Fig. 1. Remanent magnetization between the town of Raahe and Lake Ladoga (the Main Sulphide Ore Belt of Kahma 1973). 1. Basement complex within the Main Sulphide Ore Belt. 2. Approximate area of the Main Sulphide Belt. 3. Subsilicic intrusions within the Belt. 4. Major fracture. 5. Area of the detailed maps in Fig. 2. and Fig. 3. Remanent magnetization shown on the Lambert equal area projection nets. The average direction shown as a tirangle. Table numbers refer to Tables in the text and pole numbers to the poles in Fig. 8. 
gravity trough in the $325^{\circ}$ direction is probably »the manifestation of a larger zone of crustal weakness». According to him, the crustal block east of the town of Kuopio (see Fig. 1) is subsiding and causing the earthquakes recently registered in the area. In the Iisalmi area (Fig. 1) Kauppinen (1973) has mapped several blocks which he assumed to have moved vertically in respect to each other. Parkkinen (1975) made a deformation analysis of a mafic intrusion in the southeastern part of the Belt. In his opinion, the wrench zones parallel to the Belt are caused by the oldest regional stress in a NE-SW direction. Marttila (1976) adopted the conception of geosynclinal sedimentation of the supracrustal series in the Kiuruvesi area northwest of Kuopio. He interpreted the NWstriking Belt as a subsiding rift valley system connected with subparallel faults, shear zones and extrusive and intrusive magmatism.

The purpose of the present paper is to report on the paleomagnetic data obtained for the Belt area and to compare them with paleomagnetic data on the Archean basement region just north of it. The aim is to throw more light on the obscure question of the origin of the Belt. The paleomagnetic measurements are concentrated on two areas: One is in the central part of the Main Sulphide Ore Belt in the Haukivesi area, the other is just north of the Belt in the Archean basement complex in the Nilsiä-Varpaisjärvi area (Fig. 1). The lithology and paleomagnetic data obtained will be described and discussed below. Additional paleomagnetic results already available from the northwestern end of the Belt and from the Iisalmi area (see Fig. 1) will be included in the Discussion. Radiometric age data and lead isotope values will also be considered in drawing conclusions about the origin and evolution of the Belt.

\section{The lithology of the area}

Lithologically, the Belt is not well defined and its borders cannot be drawn exactly. It consists of series of metasediments and metavolcanics deformed, recrystallized and folded during the Svecokarelian (1800-1900 Ma) orogeny. These schists and gneisses are penetrated by various of intrusive rocks mainly of synkinematic character. An area typical of the Belt is met with in the southeastern part of the zone in the Haukivesi area (Figs. 1 and 2). The geology of this area will be described below as representative of the whole Belt.

For comparison, paleomagnetic samples were studied from the Nilsiä-Varpaisjärvi area (Fig. 3) northeast of the Belt. This area is part of the Presvecokarelian basement complex, Archean in age. The lithology of this area will also be described below.

\section{The Haukivesi area}

The Haukivesi area is located in the southeastern part of the Raahe-Ladoga zone (Fig. 1). The geology of the area has been described in detail by Hackman (1933), Gaál and Rauhamäki (1971) and Korsman and Pääjärvi (1980). The area is characterized by highly metamorphic supracrustal rocks and by hypersthene-bearing plutonic rocks with sporadic basic (subsilicic) dykes (Fig. 2).

The subracrustal complex consists of garnet-cordierite-sillimanite gneisses, hypersthene gneisses and hypersthene amphibolites. The garnet-cordierite-sillimanite gneisses are migmatized by trondhjemites. The metamorphism of these rocks took place under conditions of granulite facies but, according to Paavola (1976), the pressure was not very high during the recrystallization. Agglomeratic and pillow lava structures in some of the amphibolites and gneisses in the area suggest a volcanic origin for these rocks. The remanent magnetization found in these 




Fig. 2. Simplified geological map of the lake Haukivesi area. 1. gabbro, 2. hypersthene quartz diorite and diorite, 3. granodiorite, 4. high-grade gneiss and amphibolite, 5. biotite gneiss, 6. diopside amphibolite, 7. lamprophyre dyke, 8. metadiabase dyke. After Korsman and Pääjärvi (1980).

rocks is weak and unstable. Consequently, paleomagnetic investigation was not performed on the rocks of the supracrustal complex.

The supracrustal rocks are penetrated by hypersthene-bearing plutonic rocks. They consist of granodiorites, quartz diorites, diorites and minor occurrences of gabbros and uitramafic rocks. The quartz diorites and diorites are foliated and have gradual contacts towards the hypersthene gneisses and amphibolites. The magnetite content being low, only a few samples of these rocks were suitable for paleomagnetic studies although a great number of samples were collected.

The hypersthene-bearing granodiorite in the area is porphyritic. It has intrusive contacts and brecciates quartz diorites and diorites. Hence, it must be somewhat younger than those typically synorogenic rocks. No samples carrying hard magnetization were found in this rock.
There are two types of subsilicic dyke rocks of different ages in the Haukivesi area. The older ones are metadiabase dykes 1 to $2 \mathrm{~m}$ wide broken by later tectonic faults. These dykes penetrate supracrustal rocks and dioritic and more basic plutonites but they have not been observed to cut the granodiorite. Their magnetite content is low and only one diabase sample was found to carry stable magnetization.

The N-S-striking lamprophyre dykes described by Hackman (1933) represent the youngest rock in the Haukivesi area. The dykes vary in thickness from a few centimetres to some metres. They are fine-grained porphyritic rocks with plagioclase, biotite and clinopyroxene as phenocrysts. Amygdules filled with carbonate and biotite indicate crystallization at a relatively low crustal depth. The magnetite content of these dykes is usually quite high and the rock is there- 
fore suitable for paleomagnetic measurements.

Granulite facies metamorphism in the Haukivesi area is closely connected with the hypersthene-bearing intrusions. The age difference indicated by the contact relations mentioned above between the diorites and granodiorites cannot be very great. A radiometric $\mathrm{Pb}-\mathrm{U}$ age of about $1880 \mathrm{Ma}$ for both was reported by Gaál and Rauhamäki (1971). The isotopic age of the lamprophyres (1837 $\mathrm{Ma}$, see Fig. 5) is only slightly less than that of the quartz diorite and granodiorite and granodiorite. It seems likely that the geological evolution of the Haukivesi took place relatively fast between 1880 and 1840 $\mathrm{Ma}$. The area seems to have cratonized soon after the emplacement of the lamprophyre dikes about $1840 \mathrm{Ma}$ ago.

In the Pielavesi area, northwest of Haukivesi, metamorphism and plutonic intrusion evidently took place under conditions similar to those in the Haukivesi area. Granulite facies and hypersthene-bearing rocks are common. No lamprophyre dykes have been reported but diabase dykes closely associated with gabbro-diorite rocks are numerous. Some of these rocks contain remanent magnetization strong and hard enough for paleomagnetic measurements.

Closer to the Bothnian Sea, at the northwestern end of the Belt metamorphism has taken place mainly under conditions of amphibolite facies. Plutonic gabbros and diorites from this area contain large amounts of magnetite, thus making it possible to conduct paleomagnetic investigations.

\section{The Nilsiä-Varpaisjärvi area}

North of Kuopio, the boundary between the Svecokarelian rocks and the Archean basement runs subparallel to the Belt (Fig. 1). The Nilsiä-Varpaisjärvi area lies about $50 \mathrm{~km}$ north of Kuopio and the majority of the rocks in this area belong to the Archean basement complex. It is divided into two parts by the N-S-trending Proterozoic (Svecokarelian) Tahkomäki quartzite ridge (Fig. 3).

On the eastern side of the quartzite ridge, in the Lake Syväri area, the basement comprises mainly of banded and migmatitic paragneisses of diverse compositions. These gneisses are quartz dioritic or dioritic in composition with mica- and hornblende gneiss and amphibolite horizons. Narrow cordieritegneiss bands also occur. This paragneiss complex is weakly magnetized and was not studied paleomagnetically.

On the northwestern side of the Tahkomäki quartzite ridge, in the Jonsa area, northeast of Varpaisjärvi (Fig. 3), the basement differs from other Archean granite gneiss types of Finland particularly in its orthopyroxene content. The rock here is highly metamorphosed and forms a clearly limited, separate block of basement. It has a high magnetite content and is seen as a strong magnetic anomaly on the aeromagnetic map. The remanent magnetization of the rocks of the complex being very high, it is suitable for paleomagnetic investigations.

These basement rocks in the Jonsa area are cut by diabase dykes (Fig. 3) running approximately in an E-W or SE-NW direction. The width of the dykes varies from a few centimetres to about 150 metres. The contacts between the diabase and the wall rock are always very sharp, and chilled margins are usual. The diabase dyke rock is very homogeneous, massive and fine- or medium-grained. Ophitic texture is common. The best preserved dykes are composed of partly zoned plagioclase (An 40-60) and augite with some orthopyroxene. In some dykes brownish hornblende is the dominant dark mineral.

Wilkman (1924 and 1938) divided the diabase dykes in the area into enstatite-augite and hornblende dykes. Although they are somewhat different in their primary com- 


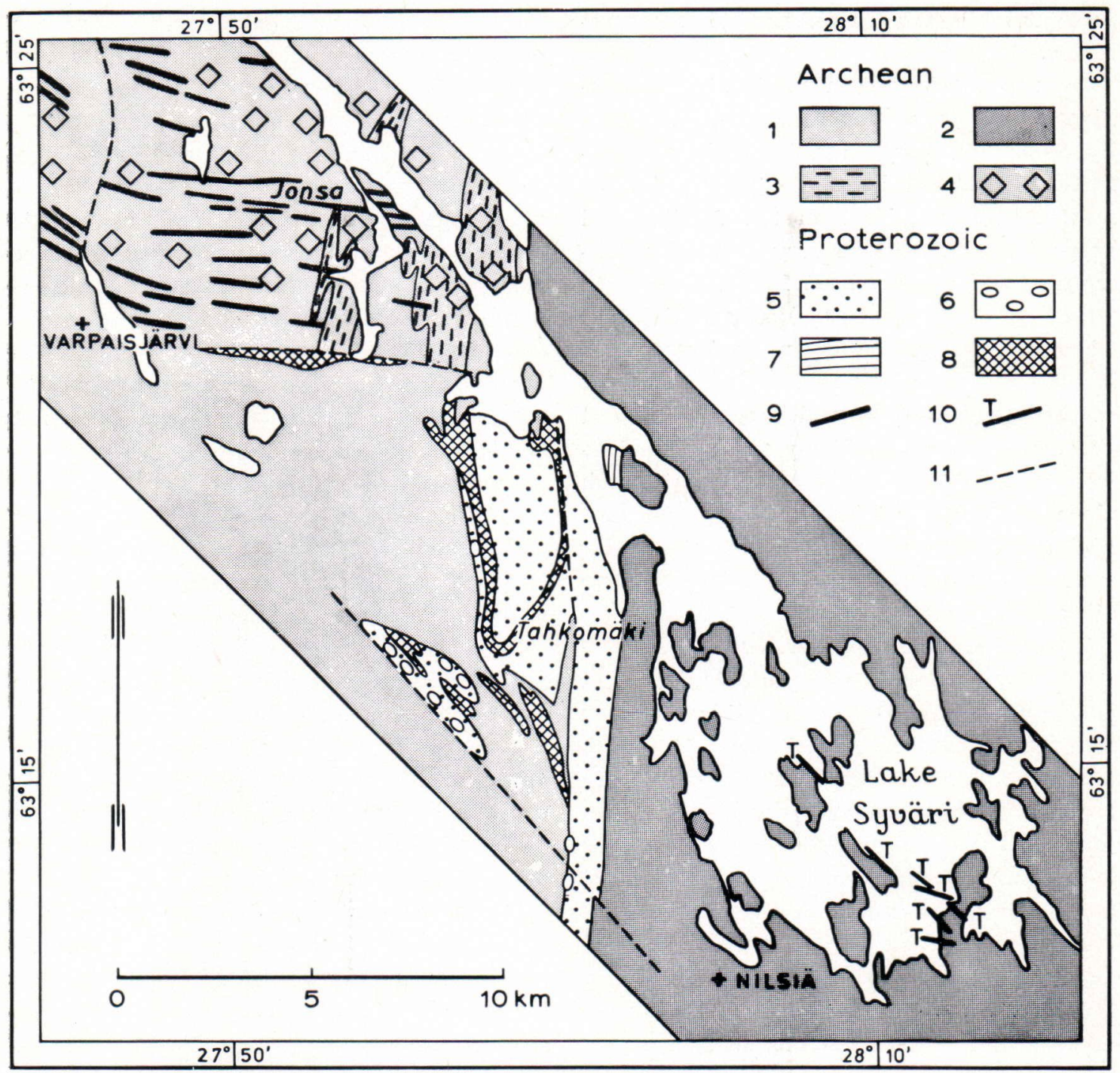

Fig. 3. Simplified geological map of the Nilsiä-Varpaisjärvi area. Archean rocks: 1. granite gneiss, 2. dominantly paragneiss, 3. pyroxene amphibolite (gabbroidic), 4. orthopyroxene. Proterozoic rocks: 5. quartzite, 6. conglomerate, 7. mica schist, 8. metadiabase, 9. diabase dyke, 10. tonalite dyke, 11. fault and fracture.

position, he considered the latter to be alteration products of the former.

Fresh and unaltered diabase dykes carry a strong and hard remanent magnetization suitable for paleomagnetic studies. According to the directions of remanent magnetization found in these dykes, they can be divided into two different types (see p. 126), which do not, however, correspond to the two petrographically different types suggested by Wilkman (op. cit.).

No radiometric dating is available for these dykes. In their chemistry and general eastwest trend the dykes are similar to the Jatulian (2150 Ma) metadiabase dykes frequently seen to cut the Presvecokarelian basement 
in eastern Finland. Consequently, these diabase dykes in the Varpaisjärvi area are thought to belong to the Jatulian age group.

A second set of intersecting dykes occurs in the Nilsiä area (Fig. 3). These dykes are finegrained, massive and homogeneous. The contacts with the wall rock are sharp and apophyses are common. The dykes are from a few centimetres to $4-5$ metres wide. Their direction varies between $\mathrm{N} 15^{\circ} \mathrm{W}$ and $\mathrm{N} 85^{\circ} \mathrm{W}$ $\left(345^{\circ}-275^{\circ}\right)$. The dip is subvertical.

The mineral composition of these dykes includes plagioclase, quartz, biotite and hornblende with accessory epidote, sphene, apatite and magnetite. Plagioclase occurs locally as intensely zoned (An 35-25) laths, 1.5-2 mm in size. According to the classification of Streckeisen (1976), these dykes have a tonalitic or quartz dioritic composition. They can be correlated with the tonalitic dykes described by Huhma (1975 and 1981) from North Karelia, with an age between 1860 and 1830 $\mathrm{Ma}$. These dykes have a weak but rather hard remanent magnetization.

\section{Radiometric datings}

Kouvo and Kulp (1961) showed that there is a distinct difference between the isotopic composition of sulphide lead in the narrow belt west of the Archean craton and that found in the craton and in the large Svecofennian area west of the Belt. They inferred that either this may suggest an earlier history for the Karelian rocks or it may represent anomalous lead with an unusual crustal environment. This lead, predating the time of the Svecokarelian synorogenic stage, was characterized by a low $\mu$-value. Interlaboratory comparisons were later performed between the U.S. Geological Survey laboratories in Denver and the Geological Survey of Finland; these showed that the low $\mu$-value is definitely real and not due to incorrect measurements of ${ }^{206} \mathrm{~Pb} /{ }^{204} \mathrm{~Pb}$ ratios. This isotopic composi- tion of sulphide lead is surprisingly homogeneous and includes polymetallic sulphide deposits such as Vihanti (Rouhunkoski, 1968), Pyhäsalmi (Stacey et al. 1977; Helovuori, 1979) and others (Vaasjoki 1981). This isotopic composition of sulphide lead has been found in the immediate vicinity of the border of the Archean craton, which consists of the evolutionary groups known as Jatulian. It thus incorporates the Main Sulphide Ore Belt in a lithostratigraphic horizon. For the present, this unique isotopic composition of sulphide lead has not been found at the southern end of the Belt. Chances of finding it, however do exist.

Aho (1979) and Helovuori (1979) have shown that the isotopic composition of the total lead of volcanic rocks from the Pihtipudas area just southwest of the Belt and from the Pyhäsalmi ore field within the Belt fit separate isochrons showing the same age within the limits of experimental uncertainty. Of an essential orogenetic significance is the fact that the point derived from the isotopic composition of sulphide lead in the Pyhäsalmi ore deposit lies on the isochron defined by the lead isotopic composition of Pyhäsalmi volcanites, whereas the Pihtipudas sulphide lead lies on the isochron of Pihtipudas volcanites.

The plumbotectonic model published by Doe and Zartman (1979) indicates a mantle origin and continental environments for the sulphide deposit in Pyhäsalmi, in the central part of the belt, whereas the lead from Pihtipudas just SW of the belt (Aho 1979), lies near to the orogenic curve (Stacey et al. 1977).

The amount of radiogenic lead isotopes generally increases towards west from the boundary of the Archean craton, and the common lead data show distinct boundaries along both sides of the belt. The isotopic data on sulphide leads indicate an age of 2100 $\mathrm{Ma}$ for the Outokumpu ore on the northeastern boundary of the belt, $1970 \mathrm{Ma}$ for the 
Pyhäsalmi ore in the central part of the belt and $1800 \mathrm{Ma}$ for the Pihtipudas occurrence just southwest outside the belt proper (Stacey et al. 1977). A comprehensive study of this subject has been undertaken by Vaasjoki (1981).

The age relations of the belt region compared with those outside the belt have been broadly defined in a number of $\mathrm{U}-\mathrm{Pb}$ investigations. Except for the Archean craton there is no reliable age difference between the intrusions in side and outside the belt.

In this work the $\mathrm{U}-\mathrm{Pb}$ isotopic relationships of zircons from the belt intrusions and Archean intrusions in the Varpaisjärvi area were studied in order to determine more precisely the age relations of the different paleomagnetic pole positions obtained.

The isotope ratios of the most concordant zircon fractions from eleven intrusions define a summary chord with an upper concordia intercept at $1892 \pm 4 \mathrm{Ma}$ (calculated accordind to York 1966; 2). The results are all from the belt intrusions extending from the Parikkala gabbro at the southeastern end of the belt to the Käpylä microcline granite at Vihanti, in the northwest.

The U-Pb data (Table 1, Fig. 4) show excellent linearity for the three density fractions of zircons from a guartz dioritic pegmatoid (A843) and for a single, almost concordant, zircon fraction heavier than $4.6 \mathrm{~g}$. $\mathrm{cm}^{-3}$ from a hypersthene-bearing quartz dioritic rock (A844) in the Varpaisjärvi area. The fitted diascordia line has an upper intersection with concordia at $2680 \pm 3 \mathrm{Ma}$ (York 1966: 2 sigma).

It has been found, especially in Finnish Lapland, that lead-lead total rock systems are disturbed and thus record a time of metamorphism, despite the quite good colinear arrays formed. However, as stated earlier, the lamprophyre dykes represent the youngest rocks in the Haukivesi area and are unmetamorphosed. The total rock sample 
Fig. 4. Concordia diagram and $\mathrm{U}-\mathrm{Pb}$ rations for zircon samples from the Varpaisjärvi quartz dioritic pegmatoid (A843) and hypersthene-bearing quartz dioritic rock (A844); Iso-Uski lamprophyre (A987); Parikkala gabbro (A884; Nykänen, unpublished); Ylivieska gabbro (A380; Pesonen and Stigzelius, 1972); Koivujärvi gabbro-diorite (A311; Helovuori, 1979); Tuli-Toiviainen mafic pegmatoid (A678; Marttila 1976); Kotalahti mafic pegmatoid (A701; Gaál 1980); Voinsalmi hypersthene granite (A382; Gaál et al., 19); Jusko qtz. diorite (A834; Helovuori, 1979); Voinsalmi hypersthene qtz. diorite (A383; Gaál et al., 19); Käpylä granite (A899; unpublished); Vaaraslahti hypersthene granite (A049; Wetherill et al., 1962); Lammasaho granodiorite (A600; Marttila, 1976). Each zircon fraction has a letter corresponding to the fractions listed in Table 1.

from which zircons were separated yielded three apatite fractions: dark brownish, yellow and transparent. Isotopic analyses of two apatites and four whole rock types (Table 2) of lamprophyre dyke in Iso-Uski are plotted on a lead-lead isochron diagram (Fig. 5). A petrographic description of these varieties of Iso-Uski lamprophyre has been given by Laukkanen (in prep.), who has also examined the different apatites used for isotopic work. The data on different rock types and apatites define a well fitted isochron based mainly on total rock groups and two points of apatites with linear regression as follows: $\mathrm{r}=0.99983$, $\mathrm{m}=0.112027 \pm 1.3058 \mathrm{E}-03$. The data given in Fig. 5 were calculated according to York
$1966(2 \sigma)$. The age yielded by lead-lead data are consistent with numerous $\mathrm{U}-\mathrm{Pb}$ and $\mathrm{Rb}-$ $\mathrm{Sr}$ ages measured on late- and post-orogenic granitoids in Finland (e.g. Neuvonen 1970; Korsman and Lehijärvi 1973; Vaasjoki 1977; Meriläinen 1976). In this connection mention should be made of the observation by Aho (1979) on the discordant zircon-titanite pair in Pihtipudas granitoids where titanites and monazite have as low ages as $1800 \mathrm{Ma}$.

Dykes like lamprophyres are found to bring up inherited material originating from wall rocks or representing early crystallization. Zircons separated from a block weighing about $40 \mathrm{~kg}$ of the Iso-Uski lamprophyre dyke yielded $5 \mathrm{mg}$ of large zircon crystals (fraction

Table 2. Analytical data on whole rock samples and two apatites from the Iso-Uski lamprophyre dyke.

\begin{tabular}{lccr}
\hline Sample No. & $206 \mathrm{~Pb} / 204 \mathrm{~Pb}$ & $207 \mathrm{~Pb} / \mathbf{2 0 4} \mathrm{Pb}$ & $208 \mathrm{~Pb} / \mathbf{2 0 4} \mathrm{Pb}$ \\
\hline JML6 whole rock & $17.770 \pm 0.034$ & $15.504 \pm 0.044$ & $36.210 \pm 0.109$ \\
JML7 whole rock & $18.018 \pm 0.048$ & $15.550 \pm 0.052$ & $36.351 \pm 0.117$ \\
JML8 whole rock & $18.190 \pm 0.017$ & $15.559 \pm 0.023$ & $36.411 \pm 0.060$ \\
JML5 whole rock & $18.229 \pm 0.005$ & $15.562 \pm 0.009$ & $36.455 \pm 0.035$ \\
A987 dark apatite & $20.564 \pm 0.017$ & $15.812 \pm 0.017$ & $36.671 \pm 0.037$ \\
A987 light coloured apatite & $26.444 \pm 0.010$ & $16.484 \pm 0.012$ & $39.019 \pm 0.031$ \\
\hline
\end{tabular}




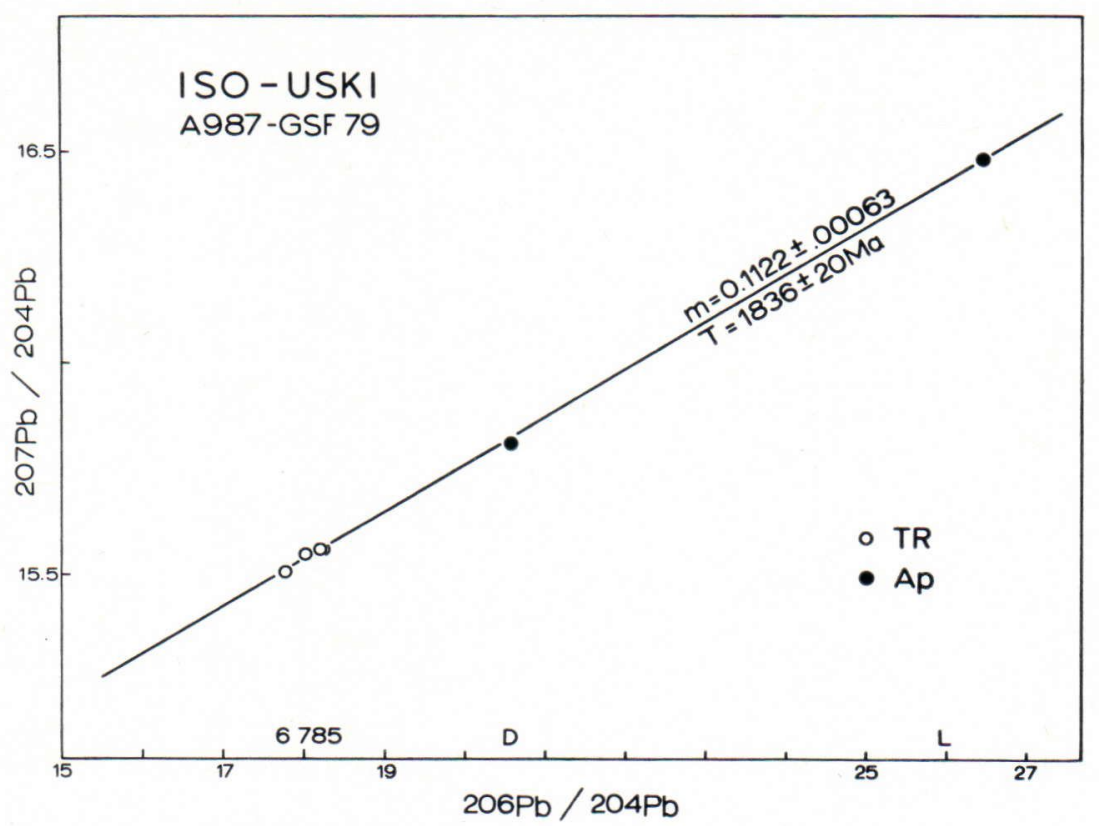

Fig. 5. $206 \mathrm{~Pb} / 204 \mathrm{~Pb}$ versus $207 \mathrm{~Pb} / 204 \mathrm{~Pb}$ in the Iso-Uski whole rock samples and two apatites. Each sample or fraction has a number or letter corresponding to analytical data listed in Table 2.

A987C), $3.5 \mathrm{mg}$ of heavy zircon (density $+4.6 \mathrm{~g} \cdot \mathrm{cm}^{-3}$ ) and about $3 \mathrm{mg}$ of zircon 4.2 $4.6 \mathrm{~g} . \mathrm{cm}^{-3}$. These zircons have been described by Laukkanen (in prep.). U-Pb data on the zircon fractions are given in Table 1, and isotope ratios are plotted on the insert graph in Fig. 5. A tentative interpretation of these fairly concordant results in that they fit different diffusion curves (Wassenburg 1963) as follows: fraction A $1905 \mathrm{Ma}(\mathrm{K}=2.0000 \mathrm{E}-$ 11/a); fraction B $1900 \mathrm{Ma}(\mathrm{K}=3.20834 \mathrm{E}-$ 11/a) fraction C $1919 \mathrm{Ma} \quad(\mathrm{K}=4.47080 \mathrm{E}-$ 11/a). Owing to the small sample size the limits of errors for single ages are quite large (e.g. $207 \mathrm{~Pb} / 206 \mathrm{~Pb}$ ages (Ma): A, $1905 \pm 22$; B, $1898 \pm 12 ; 1915 \pm 13$ ). Despite the limits of the errors it is clear that a pooled zircon chord for the Iso-Uski lamprophyre is consistently offset by $10-20 \mathrm{Ma}$ with respect to the chord for the zircons from the belt intrusions and by $70 \mathrm{Ma}$ with respect to the leadlead isochron of whole rocks and apatites. From field evidence it is clear that the zircons are not coeval with the crystallization of the Iso-Uski whole rock. This effort to establish the qualified tectonic framework provides

the following view of the Proterozoic history of the $1900 \mathrm{Ma}$ group:

\begin{tabular}{lll}
\hline & & Age (Ma) \\
\pm 2 error \\
Rock body Locality Reference & $\begin{array}{l}\text { (concordia } \\
\text { intercept) }\end{array}$ \\
\hline
\end{tabular}

\section{Parikkala} gabbro

Voinsalmi intrusions

Kotalahti diorite and mafic pegmatoid

Koivujärvi gb. diorite

Vaaraslahti hy. granite Jusko qtz. diorite

Kettuperä

gneiss

Käpylä granite Tuli-Toiviainen mafic pegmatoid Ylivieska gabbro

\begin{tabular}{|c|c|c|}
\hline $\begin{array}{l}\text { Kesus- } \\
\text { maa } \\
\text { Saari }\end{array}$ & $\begin{array}{l}\text { Nykänen, } \\
\text { in prep. }\end{array}$ & $1886 \pm 1$ \\
\hline $\begin{array}{l}\text { Ranta- } \\
\text { salmi }\end{array}$ & $\begin{array}{l}\text { Gaál et al., } \\
1971 \text { and un- } \\
\text { published }\end{array}$ & $1884 \pm 13$ \\
\hline $\begin{array}{l}\text { Leppä- } \\
\text { virta }\end{array}$ & Gaál 1980 & $1882 \pm 1$ \\
\hline $\begin{array}{l}\text { Piela- } \\
\text { vesi }\end{array}$ & $\begin{array}{l}\text { Helovuori } \\
1979 \text { and un- } \\
\text { published }\end{array}$ & $1892=$ \\
\hline $\begin{array}{l}\text { Piela- } \\
\text { vesi }\end{array}$ & unpublished & $1884 \pm 9$ \\
\hline $\begin{array}{l}\text { Pyhä- } \\
\text { salmi }\end{array}$ & $\begin{array}{l}\text { Helovuori } \\
1979\end{array}$ & $1893 \pm 3$ \\
\hline $\begin{array}{l}\text { Pyhä- } \\
\text { salmi }\end{array}$ & $\begin{array}{l}\text { Helovuori } \\
1979\end{array}$ & $1932 \pm 3$ \\
\hline Vihanti & unpublished & $1886 \pm 5$ \\
\hline $\begin{array}{l}\text { Kiuru- } \\
\text { vesi }\end{array}$ & Marttila 1981 & $1886=$ \\
\hline $\begin{array}{l}\text { Yli- } \\
\text { vieska }\end{array}$ & $\begin{array}{l}\text { Pesonen and } \\
\text { Stigzelius } 1972\end{array}$ & $\begin{array}{l}1884 \\
\text { (nearly } \\
\text { concor- } \\
\text { dant) }\end{array}$ \\
\hline
\end{tabular}


The data presented provide an internally consistent framework, which includes the Pihtipudas intrusions outside the belt. An older event is represented by the Kettuperä gneiss described by Helovuori (1979).

The ages were all calculated according to the following decay constants $\left(10^{-9} \mathrm{a}^{-1}\right):{ }^{238} \mathrm{U}$ : 0.155125 ; ${ }^{235} \mathrm{U}: 0.984850$.

The $\mathrm{K}-\mathrm{Ar}$ and $\mathrm{Rb}-\mathrm{Sr}$ ages for biotite from the Vaaraslahti pyroxene granite show fair agreement at $1760 \mathrm{Ma}$ and $1730 \mathrm{Ma}$ (Wetherill et al. 1962). Similar K-Ar mica ages have been found for other granitoids and schists in S. Finland, irrespective of their stratigraphic position, and thus provide a minimum age for the last regional cooling event.

\section{Paleomagnetic measurements}

Rocks suitable for paleomagnetic measurements were found both inside and outside the Belt area. Within the Belt, in the Haukivesi area, three different rock types with hard enough remanence were drilled: 1) hypersthene-bearing quartz diorites, 2) diabase dykes, and 3) lamprophyre dykes. Contact relations indicate that the lamprophyre dykes are the youngest in the area. They are also the most suitable for paleomagnetic work because of their hard and stable magnetization. The quartz diorites and diabase dykes are weakly magnetized and thus only in three samples was remanent magnetization detected with the instrument available (Forster-type fluxgate spinner, Forster 1966) despite the large collection of oriented samples drilled. Fortunately, the same rock types with more stable magnetization are found in the Pielavesi-Kiuruvesi area. Additional paleomagnetic data on the Belt area are available thanks to the work of Pesonen and Stigzelius (1972) on Ylivieska and other areas at the northwestern end of the Sulphide Ore Belt.
Three rock types yielding reliable paleomagnetic results were collected for the basement region in the Varpaisjärvi-Nilsiä area: 1) hypersthene-bearing dioritic basement gneiss, 2) diabase dykes cutting the basement, and 3) tonalite dykes representing the youngest rock in the area. For comparison, additional samples were drilled from plutonic subsilicic intrusive rocks and diabase dykes in the Iisalmi region northwest of Varpaisjärvi (Fig. 1).

The samples were drilled and oriented in the field with a sun compass on glacially polished, fresh surfaces. The stability of the remanence was tested by progressive demagnetization up to 90 or $100 \mathrm{mT}$ and checked by heating. As a rule no secondary component was detected besides the VRM: Usually, only those samples were accepted which yielded a circle of confidence less than $20^{\circ}$ and a low $\theta_{63}$-value (Pesonen 1973) as positive tests for stability.

Remanent magnetization of the intrusive rocks in the Haukivesi area

The only rock type which gave really reliable results in the form of stable remanent magnetization in the Haukivesi region were the lamprophyre dykes encountered on small islands in the lake Haukivesi (Fig 2). The 26 samples drilled at 12 sites all yielded a stable direction of remanent magnetization (Table 3 and Fig. 1). The samples were cleaned with af- and heat-treatments; both methods gave a similar end point (Fig. 6). In contrast, only two samples from a large collection of gabbro, diorite and quartz diorite samples had hard magnetization. Their magnetic directions join with the direction measured on a narrow diabase dyke from the same area and are shown in Table 3 .

Although, as suggested by the cutting con- 
Table 3. Remanent magnetization of basic intrusions in the Haukivesi area.

\begin{tabular}{|c|c|c|c|c|c|c|c|c|c|c|c|c|}
\hline \multirow{2}{*}{$\begin{array}{l}\text { Sample } \\
\text { No. }\end{array}$} & \multirow[b]{2}{*}{ Rock type } & \multirow[b]{2}{*}{ Locality } & \multirow[b]{2}{*}{$\mathrm{N}$} & \multirow[b]{2}{*}{$\mathrm{n}$} & \multicolumn{8}{|c|}{ Remanent magnetization after cleaning } \\
\hline & & & & & $\begin{array}{l}\text { Decl. } \\
\text { (deg.) }\end{array}$ & $\begin{array}{l}\text { Incl. } \\
\text { (deg.) }\end{array}$ & $\begin{array}{c}\text { Intensity } \\
(\mathrm{A} / \mathrm{m})\end{array}$ & $\begin{array}{c}\alpha 95 \\
\text { (deg.) }\end{array}$ & $\mathrm{k}$ & $\mathrm{R}$ & Demagn. & Remarks \\
\hline 7333 & Lamprophyre dyke & $\begin{array}{l}\text { Pikku Pöljä, } \\
\text { E Rantasalmi }\end{array}$ & 1 & 12 & 347 & 32 & .873 & 4 & 112.7 & 11.902 & $40 \mathrm{mT}$ & Af \\
\hline 7705 & $-»-$ & $\begin{array}{l}\text { Iso-Uski, } \\
\text { Savonlinna }\end{array}$ & 1 & 10 & 357 & 37 & .212 & 1 & 1973 & 9.995 & $80 \mathrm{mT}$ & Af \\
\hline 7707 & $-»-$ & $\begin{array}{l}\text { Selkä-Anttonen, } \\
\text { Rantasalmi }\end{array}$ & 2 & $10+10$ & 352 & 33 & .118 & $(2+8)$ & 340 & 1.997 & $80 \mathrm{mT}$ & Af \\
\hline 7801 & $-»-$ & $\begin{array}{l}\text { Nuottaluoto, } \\
\text { Rantasalmi }\end{array}$ & 2 & $10+9$ & 347 & 29 & .146 & $(2+2)$ & 811 & 1.998 & $45 \mathrm{mT}$ & Af \\
\hline 7802 & $-»-$ & $\begin{array}{l}\text { Tiheinen, } \\
\text { E Rantasalmi }\end{array}$ & 2 & $9+9$ & 346 & 41 & .078 & $(8+2)$ & 55.3 & 1.981 & $45 \mathrm{mT}$ & Af \\
\hline 7803 & $-»-$ & $\begin{array}{l}\text { Kirvesluoto, } \\
\text { E Rantasalmi }\end{array}$ & 2 & $10+6$ & 349 & 38 & .035 & $(5+5)$ & 1518 & 1.999 & $45 \mathrm{mT}$ & Af \\
\hline 7804 & -»- & $\begin{array}{l}\text { Tiheinen, } \\
\text { N Rantasalmi }\end{array}$ & 3 & $8+10+10$ & 343 & 40 & .062 & 7 & 296.3 & 2.993 & $50 \mathrm{mT}$ & Af \\
\hline 7805 & $-»-$ & $\begin{array}{l}\text { Iso-Uski, } \\
\text { Savonlinna }\end{array}$ & 2 & $8+10$ & 346 & 41 & .242 & $(1+1)$ & 1254 & 1.999 & $500^{\circ} \mathrm{C}$ & Heated \\
\hline 7806 & $-»-$ & $\begin{array}{l}\text { Iso-Uski, } \\
\text { Savonlinna }\end{array}$ & 2 & $9+10$ & 341 & 43 & .312 & $(2+2)$ & 13120 & 1.999 & $45 \mathrm{mT}$ & Af \\
\hline 7807 & $-»-$ & $\begin{array}{l}\text { Selkä-Anttonen, } \\
\text { Rantasalmi }\end{array}$ & 5 & $10+5$ & 354 & 45 & .285 & 8 & 91.8 & 4.956 & $450^{\circ} \mathrm{C}$ & Heated \\
\hline 7808 & $-»-$ & $\begin{array}{l}\text { Maa-Anttonen, } \\
\text { S Rantasalmi }\end{array}$ & 1 & 10 & 346 & 37 & .121 & 9 & 31.2 & 9.971 & $45 \mathrm{mT}$ & Af \\
\hline 7809 & -»- & $\begin{array}{l}\text { Maa-Anttonen, } \\
\text { W Rantasalmi }\end{array}$ & 2 & $10+10$ & 347 & 39 & .382 & $(5+3)$ & 300.2 & 1.996 & $450^{\circ} \mathrm{C}$ & Heated \\
\hline \multicolumn{2}{|c|}{ Average lamprophyres } & $28.43^{\circ} \mathrm{E} \quad 62.13^{\circ} \mathrm{N}$ & 12 & - & 348 & 38 & 一 & 3.1 & 192.4 & 11.942 & \multicolumn{2}{|c|}{$\begin{array}{c}\text { Pole } 225^{\circ} \mathrm{E}, 48^{\circ} \mathrm{N} \\
\mathrm{dm}=3.7^{\mathrm{c}} \\
\mathrm{dp}=2.2^{\circ}\end{array}$} \\
\hline 7329 & Hy-qu-diorite & $\begin{array}{l}\text { Torasalo, } \\
\text { Rantasalmi }\end{array}$ & 1 & 11 & 346 & 53 & .180 & 7 & 49.1 & 10.797 & $40 \mathrm{mT}$ & Af \\
\hline 7330 & $-»-$ & $\begin{array}{l}\text { Porosalmi, } \\
\text { Rantasalmi }\end{array}$ & 1 & 10 & 350 & 30 & .124 & 23 & 5.3 & 8.309 & $40 \mathrm{mT}$ & Af \\
\hline 7703 & Diabase dyke & $\begin{array}{l}\text { Näätäsaari, } \\
\text { Rantasalmi }\end{array}$ & 1 & 10 & 349 & 49 & 0.013 & 7 & 45.9 & 9.804 & $50 \mathrm{mT}$ & Af \\
\hline \multicolumn{2}{|c|}{ Average diorites and diabase } & $28.28^{\circ} \mathrm{E} \quad 62.15^{\circ} \mathrm{N}$ & 3 & - & 349 & 44 & - & 19 & 44.6 & 2.955 & \multicolumn{2}{|c|}{$\begin{array}{c}\text { Pole } 225^{\circ} \mathrm{E}, 53^{\circ} \mathrm{N} \\
\mathrm{dm}=24^{\circ} \\
\mathrm{dp}=15^{\circ}\end{array}$} \\
\hline \multicolumn{3}{|c|}{ Total average Haukivesi area $28.40^{\circ} \mathrm{E} \quad 62.13^{\circ} \mathrm{N}$} & 15 & - & 348 & 39 & - & 3.4 & 130.8 & 14.893 & & \\
\hline
\end{tabular}

Mean paleomagnetic pole position $225.4^{\circ}$ east, $49.0^{\circ}$ north, $\delta \mathrm{m}=4.1^{\circ}, \delta \mathrm{p}=2.4^{\circ}$

$\mathrm{N}=$ number of cores, $\mathrm{n}=$ number of specimens, $\alpha=$ circle of confidence at $95 \%$ probability, $\mathrm{k}=$ estimate of the precision parameter, $\mathrm{R}=$ resultant of the unit vectors 
Fig. 6. Demagnetization of the lamprophyre dyke rock. Specimen 7804.15 demagnetized with alternating magnetic field (af) treatment. Specimen 7809.21 demagnetized by heating.

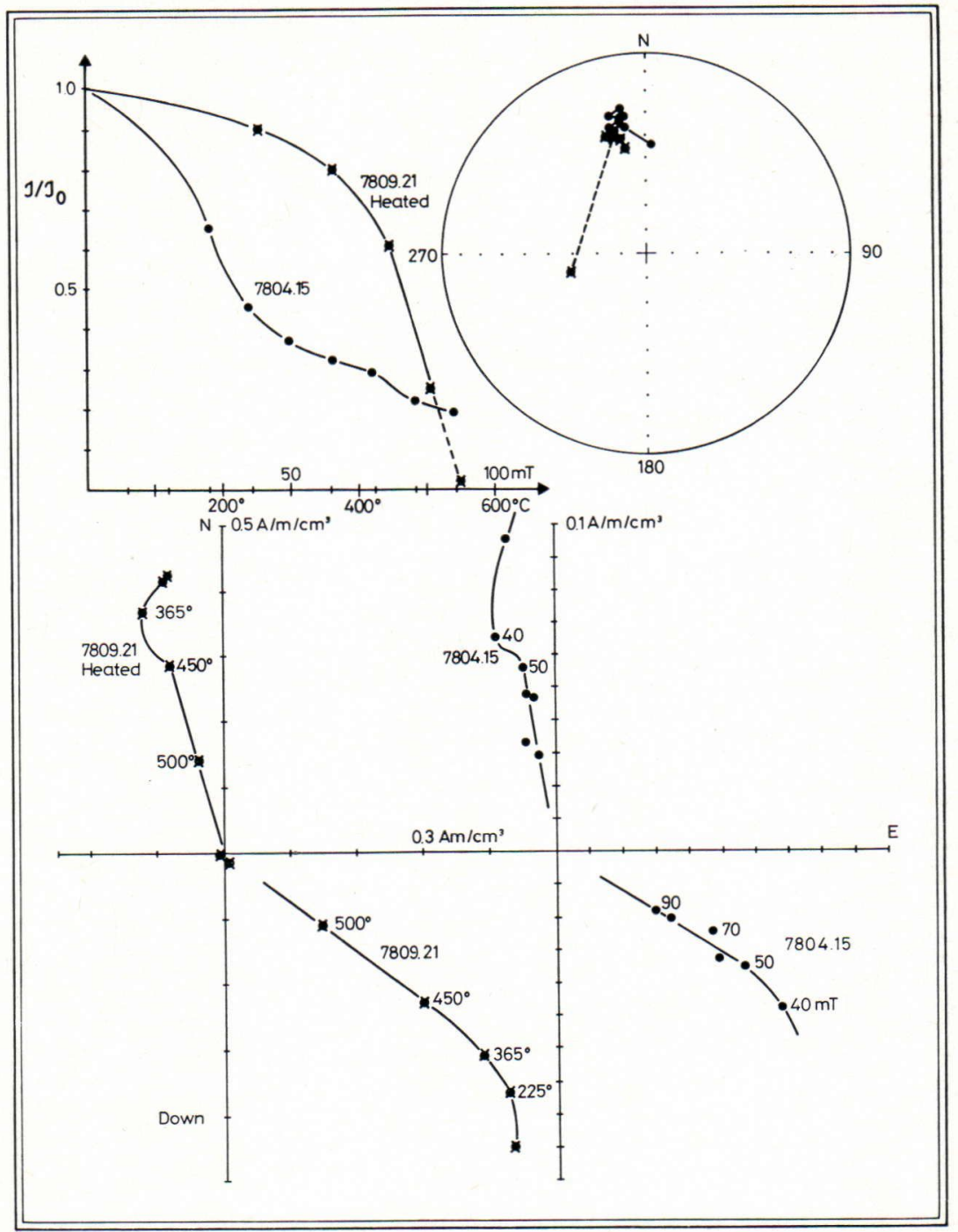

tact relations, the dyke rocks must be somewhat younger than the plutonic rocks, the directions of the remanent magnetization do not differ markedly. The paleomagnetic pole positions calculated on the basis of these directions are plotted on the APW path given for the Baltic Shield by Pesonen and Neuvonen (1981) in Fig. 8 as pole numbers 1 and 2 (subsilicic intrusions and lamprophyre dykes, respectively).
Remanent magnetization of the subsilicic intrusions in Kiuruvesi-Pielavesi area

The Kiuruvesi-Pielavesi area, which lies about $150 \mathrm{~km}$ northwest of the Haukivesi area is characterized by the same type of hypersthene-bearing plutonic rocks and similar diabase dykes as those encountered in the Haukivesi area. These rocks are, however, more strongly magnetized than those in the 


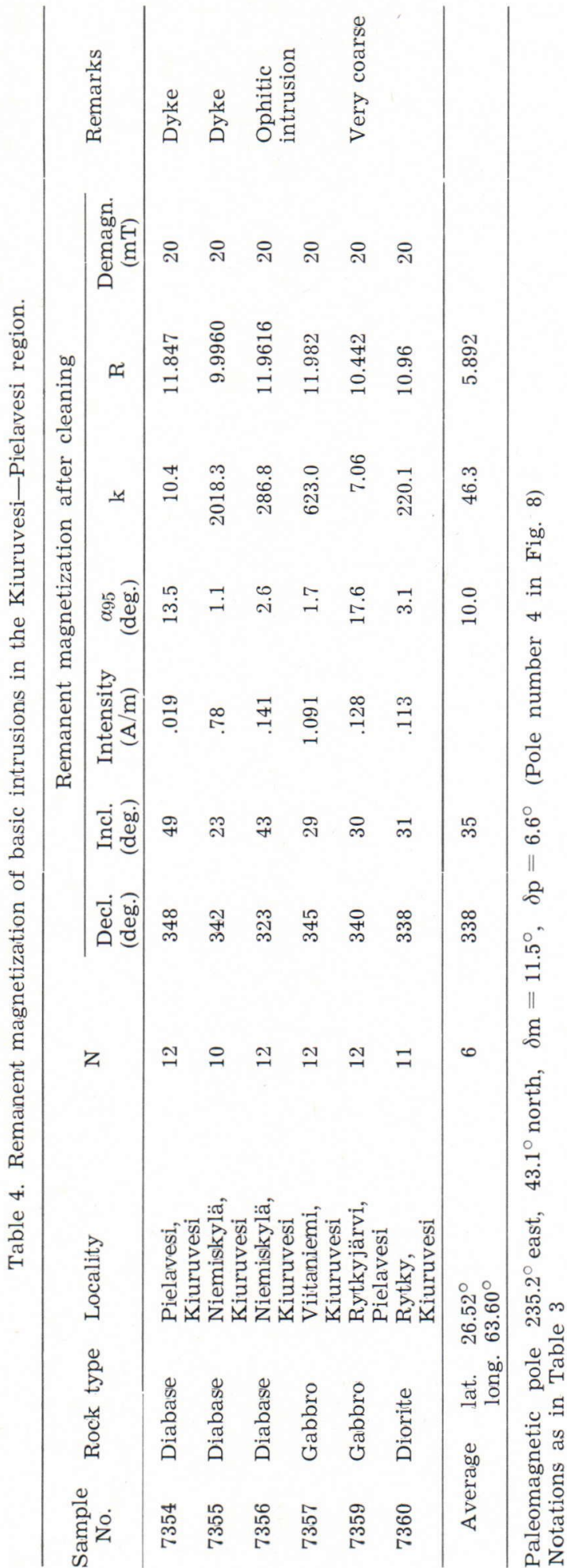

Haukivesi area; hence, the paleomagnetic results are more reliable. The paleomagnetic pole position measured on gabbro from this area has been reported by Pesonen and Neuvonen (1981) to be $238.2^{\circ} \mathrm{E}$ and $35.9^{\circ} \mathrm{N}$; it is plotted here in Fig. 8 as pole number 3. A very similar pole was calculated from the values measured on two gabbro samples and four diabase sites sampled in the KiuruvesiPielavesi area by the present authors (Table 4). The paleomagnetic pole position given by these samples is $235.2^{\circ} \mathrm{E}$ and $43.1^{\circ} \mathrm{N}$ (pole number 4 in Fig. 8). The hypersthene gabbros in this area are assumed to be synorogenic and somewhat less than $1900 \mathrm{Ma}$ in age (Marttila 1976), see Table 1 . The diabase dykes are evidently very similar in age, although they are undeformed and clearly intersecting the metamorphic rocks in the area.

A baked contact test, which might have given additional information on the nature of the paleomagnetism of the area, was not performed.

Paleomagnetism of the subsilic intrusions at the northwestern end of the sulphide ore belt

Pesonen and Stigzelius (1972) carried out a paleomagnetic investigation of the gabbros and related intrusive rocks at the northwestern end of the Belt (Pohjanmaa region). They studied the remanent magnetization of a large noritic gabbro in Ylivieska and of eight other gabbro-diorite bodies in the Pohjanmaa region which, according to Salli (1965), form a comagmatic synorogenic series. Hard and stable magnetization was found in Ylivieska and in five other intrusions in the area (Fig. 1). The pole site given by the Ylivieska gabbro is $242.2^{\circ} \mathrm{E}$ and $43.3^{\circ} \mathrm{N}$ and is reproduced as pole number 5 in Fig. 8. The other Pohjanmaa gabbros give a paleomagnetic pole at $239.1^{\circ} \mathrm{E}, 37.9^{\circ} \mathrm{N}$; it is shown as number 6 in Fig. 8. 
According to Pesonen and Stigzelius (1972), the deviation observed in the magnetic directions in the area can be assumed to be caused by paleosecular variation in the ancient geomagnetic field.

\section{Remanent magnetization in the}

Varpaisjärvi-Nilsiä area

Paleomagnetic measurements were carried out on the hypersthene-bearing basement complex, diabase dykes and tonalite dykes in the Varpaisjärvi-Nilsiä area. Drilled at a number of sites NE of Varpaisjärvi (Fig. 3), the basement rock yielded unaltered, well preserved rock types with stable and hard magnetization (Fig. 7). The directions of remanent magnetization after af-cleaning measured for the hypersthene-bearing basemient are listed in Table 5. The NRM of these samples was very hard and did not markedly change in direction during af-demagnetization after removal of the viscous component (Fig. 7). The paleomagnetic pole position determined by the remanent magnetization measured for these hypersthene basement rocks $\left(313.0^{\circ} \mathrm{E}\right.$ and $\left.63.9^{\circ} \mathrm{N}\right)$ differs greatly from all other paleopoles measured for the Baltic Shield. This pole was used by Pesonen and Neuvonen (1981) as a $2680 \mathrm{Ma}$ old key pole in their construction of the APW path for the Baltic Shield. This pole is shown as the pole number 11 in Fig. 8.

The hypersthene-bearing basement block in Jonsa, NE of Varpaisjärvi (Fig. 3), is cut by diabase dikes running east-west as described above (p. 113). These dykes are weakly magnetized although some unaltered samples contain hard and stable magnetization (Fig. 7). The af-cleaned directions measured on these diabase dikes are listed in Table 6 . The paleomagnetic pole $187.8^{\circ} \mathrm{E}$ and $47.1^{\circ} \mathrm{N}$, is plotted as number 7 in Fig. 8.

To test the primarity of the magnetization measured, a baked contact test (Everitt and

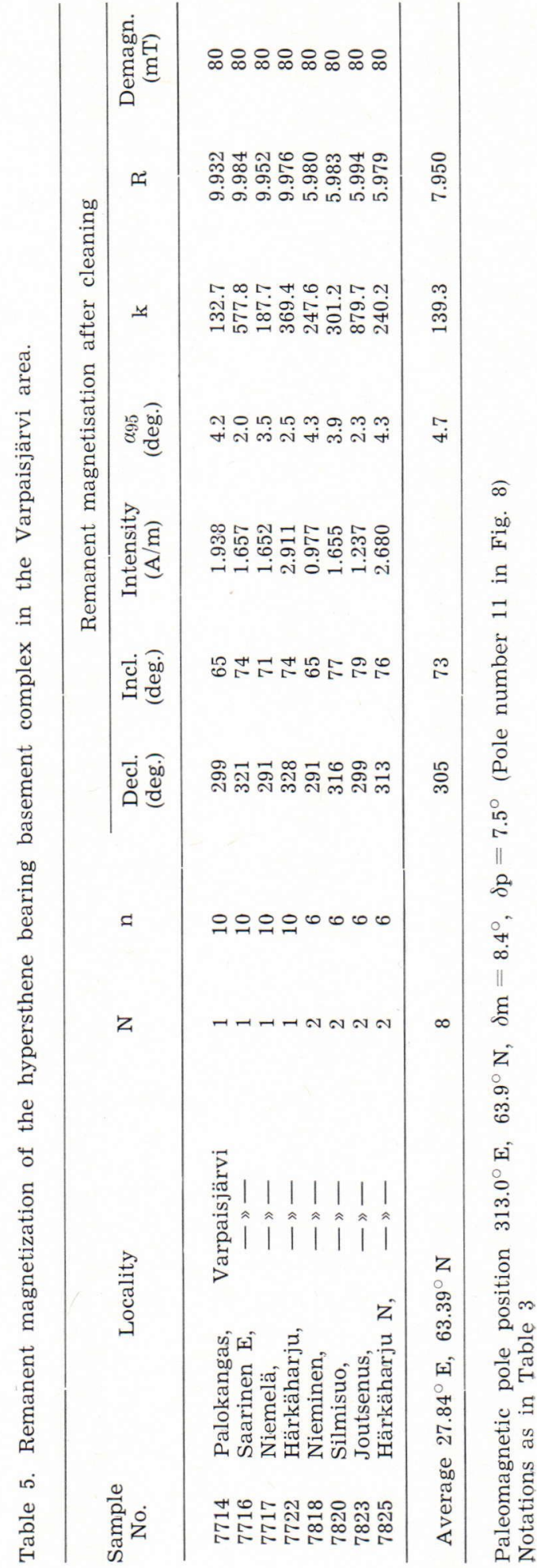




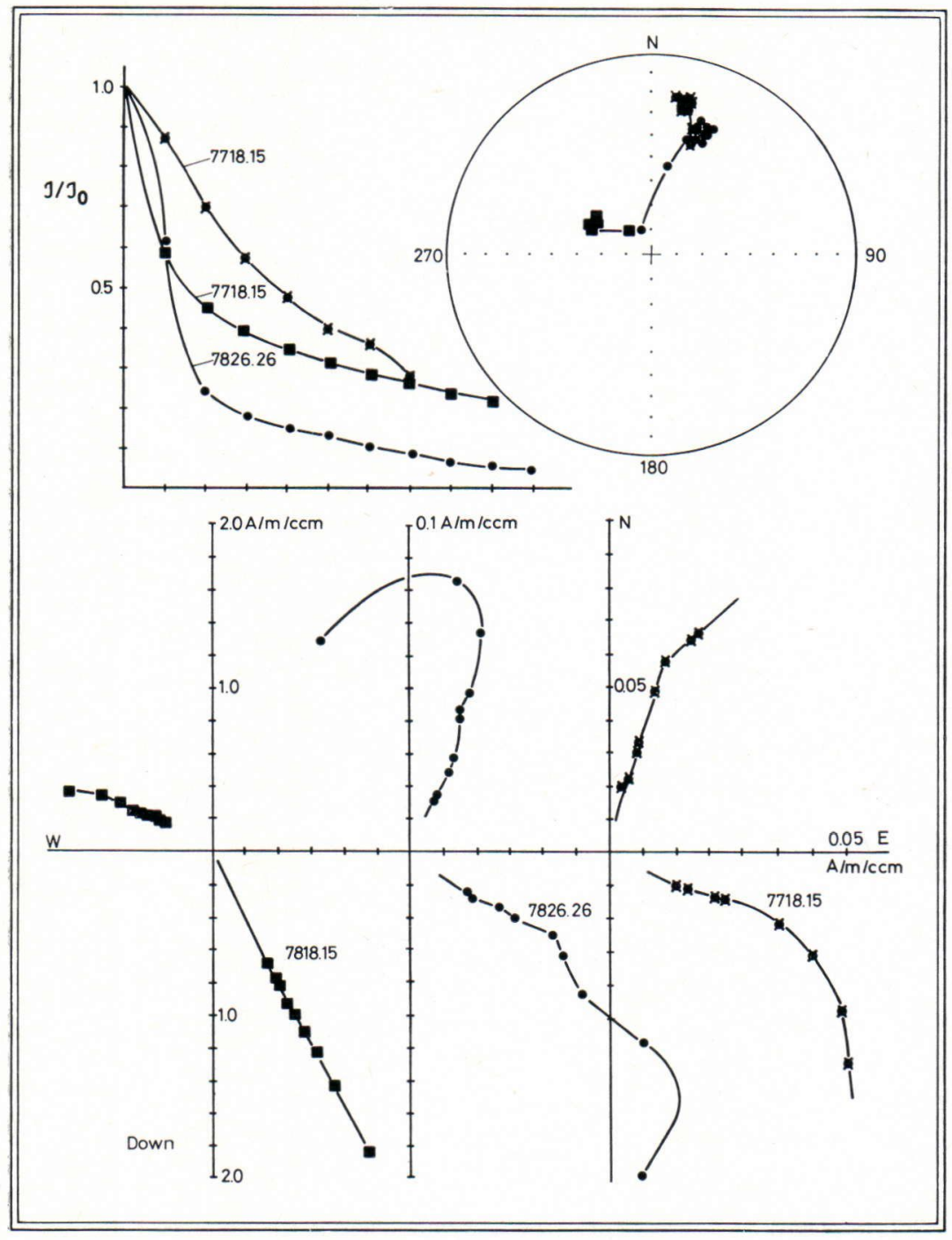

Fig. 7. Demagnetization of samples from Varpaisjärvi area. Specimen 7818.15 hypersthene diorite demagnetized with af-treatment. Specimen 7826.26 hypersthene diorite about $7 \mathrm{~cm}$ from the diabase contact (at-treatment). Specimen 7718.15 cutting diabase demagnetized with af-treatment.

Clegg 1962 and Pesonen 1978) was carried out. As seen in Table 7, the declination and inclination values are unaffected about $100 \mathrm{~m}$ from the contact of a diabase dyke over $25 \mathrm{~m}$ wide. When approaching the contact the direction of remanent magnetization gradually moves towards the direction of the dyke rock. Consequently, it can be assumed that the heat transferred from the dyke has remagnetized the wall rock. The gradual change in wall rock magnetization confirms that the magnetizations measured on both the diabase and the unaffected basement rock are of primary TRM.

Stable magnetization was also measured on some samples from the tonalite dykes in Nilsiä, in the southern part of the Lake Syväri area (see Fig. 3 and p. 115). The direction of remanent magnetization of these dykes is given in Table 8 . The remanent magnetization is weak but hard, and the average direction for the five dykes differs but little from 
Table 6. Diabase dykes of the Varpaisjärvi area, type 1.

\begin{tabular}{|c|c|c|c|c|c|c|c|c|c|c|c|}
\hline \multirow[b]{2}{*}{$\begin{array}{l}\text { Sample } \\
\text { No. }\end{array}$} & \multirow[b]{2}{*}{ Locality } & \multirow[b]{2}{*}{$\mathrm{N}$} & \multirow[b]{2}{*}{$\mathrm{n}$} & \multicolumn{8}{|c|}{ Remanent magnetization after AC-cleaning } \\
\hline & & & & $\begin{array}{l}\text { Decl. } \\
\text { (deg.) }\end{array}$ & $\begin{array}{l}\text { Incl. } \\
\text { (deg.) }\end{array}$ & $\begin{array}{l}\text { Intensity } \\
(\mathrm{A} / \mathrm{m})\end{array}$ & $\begin{array}{c}\alpha_{95} \\
\text { (deg.) }\end{array}$ & $\mathrm{k}$ & $\mathbf{R}$ & $\begin{array}{l}\text { Demagn. } \\
(\mathrm{mT})\end{array}$ & Remarks \\
\hline 7718.1 & Hanhimäki & 1 & 10 & 12 & 25 & 0.047 & 2 & 503.6 & 9.982 & 40 & Af \\
\hline 7720.1 & Saarnakallio & 1 & 10 & 13 & 44 & 0.028 & 9 & 32.7 & 9.724 & 50 & $»$ \\
\hline 7723.1 & Härkäharju & 1 & 10 & 15 & 35 & 0.242 & 1 & 1784 & 9.995 & 50 & $»$ \\
\hline 7816.3 & Nieminen & 1 & 8 & 15 & 54 & 0.031 & 10 & 30.1 & 7.770 & 50 & $\begin{array}{l}\text { Baked } \\
\text { contact, Af }\end{array}$ \\
\hline $7817.1-2$ & Nieminen & 2 & $10+10$ & 27 & 45 & 0.067 & (9) & 1068 & 1.991 & 40 & Af \\
\hline $7821.1-2$ & Hanhimäki & 2 & $9+10$ & 8 & 32 & 0.028 & (5) & 198.3 & 1.995 & 50 & $»$ \\
\hline $7824.1-2$ & Joutsenus & 2 & $10+10$ & 10 & 34 & 0.145 & (2) & 729.9 & 1.999 & 50 & $»$ \\
\hline 7826.2 & Jonsanharju & 1 & 3 & 20 & 32 & 0.081 & 5.2 & 555.7 & 2.996 & 50 & $»$ \\
\hline $7827.1-2$ & Saarnakallio & 2 & $10+10$ & 9 & 44 & 0.027 & $(5)$ & 276.4 & 1.996 & 40 & $»$ \\
\hline $7829.1-2$ & Suomäki & 2 & $10+10$ & 9 & 37 & 0.212 & (4) & 781.6 & 1.998 & 30 & $»$ \\
\hline $7831.1-2$ & Palomäki & 2 & $10+10$ & 24 & 41 & 0.020 & (12) & 35.3 & 1.971 & 40 & $»$ \\
\hline Average & $\begin{array}{l}\text { lat. } 27.91^{\circ} \mathrm{E} \\
\text { long. } 63.38^{\circ} \mathrm{N}\end{array}$ & 11 & & 15 & 38 & - & 5.4 & 73.35 & 10.863 & & \\
\hline
\end{tabular}

Paleomagnetic pole position $187.8^{\circ} \mathrm{E}, 47.1^{\circ} \mathrm{N}, \delta \mathrm{m}=6.4^{\circ}, \delta \mathrm{p}=3.8^{\circ} \quad$ (Pole number 7 in Fig. 8)

Notations as in Table 3

Table 7. Remanent magnetization of the hypersthene-bearing basement rock in contact with the diabase dyke.

\begin{tabular}{|c|c|c|c|c|c|c|c|c|c|c|}
\hline \multirow{2}{*}{$\begin{array}{l}\text { Sample } \\
\text { No. }\end{array}$} & \multirow[b]{2}{*}{ Locality } & \multirow{2}{*}{$\begin{array}{l}\text { Distance from } \\
\text { the contact }\end{array}$} & \multirow[b]{2}{*}{$\mathrm{N}$} & \multicolumn{7}{|c|}{ Direction of the magnetization after AC-cleaning } \\
\hline & & & & $\begin{array}{l}\text { Decl. } \\
\text { (deg.) }\end{array}$ & $\begin{array}{l}\text { Incl. } \\
\text { (deg.) }\end{array}$ & $\begin{array}{l}\text { Intensity } \\
(\mathrm{A} / \mathrm{m})\end{array}$ & $\begin{array}{c}\alpha_{95} \\
\text { (deg.) }\end{array}$ & $\mathrm{k}$ & $\mathrm{R}$ & $\begin{array}{c}\text { Demagn. } \\
(\mathrm{mT})\end{array}$ \\
\hline 7818.1 & $\begin{array}{l}\text { Nieminen, } \\
\text { Varpaisjärvi }\end{array}$ & $>100 \mathrm{~m}$ & 6 & 291 & 65 & .977 & 4.3 & 247.7 & 5.980 & 80 \\
\hline 7826.3 & $\begin{array}{l}\text { Jonsanharju, } \\
\text { Varpaisjärvi }\end{array}$ & $1.2 \mathrm{~m}$ & 6 & 354 & 34 & .152 & 2.8 & 561.7 & 5.9911 & $50-80$ \\
\hline 7816.1 & $\begin{array}{l}\text { Nieminen, } \\
\text { Varpaisjärvi }\end{array}$ & c. $1 \mathrm{~m}$ & 10 & 359 & 42 & & 9.7 & 25.8 & 9.652 & 50 \\
\hline 7816.2 & $-»-$ & c. $1 \mathrm{~m}$ & 10 & 5 & 37 & & 4.0 & 143.7 & 9.937 & 50 \\
\hline 7816.3 & $-»-$ & $0.2 \mathrm{~m}$ & 8 & 15 & 54 & .031 & 10.3 & 10.2 & 7.768 & 50 \\
\hline 7826.2 & $\begin{array}{l}\text { Jonsanharju, } \\
\text { Varpaisjärvi }\end{array}$ & $7 \mathrm{~cm}$ & 3 & 20 & 32 & .081 & 5.2 & 555.7 & 2.9964 & 50 \\
\hline
\end{tabular}

Notations as in Table 3 


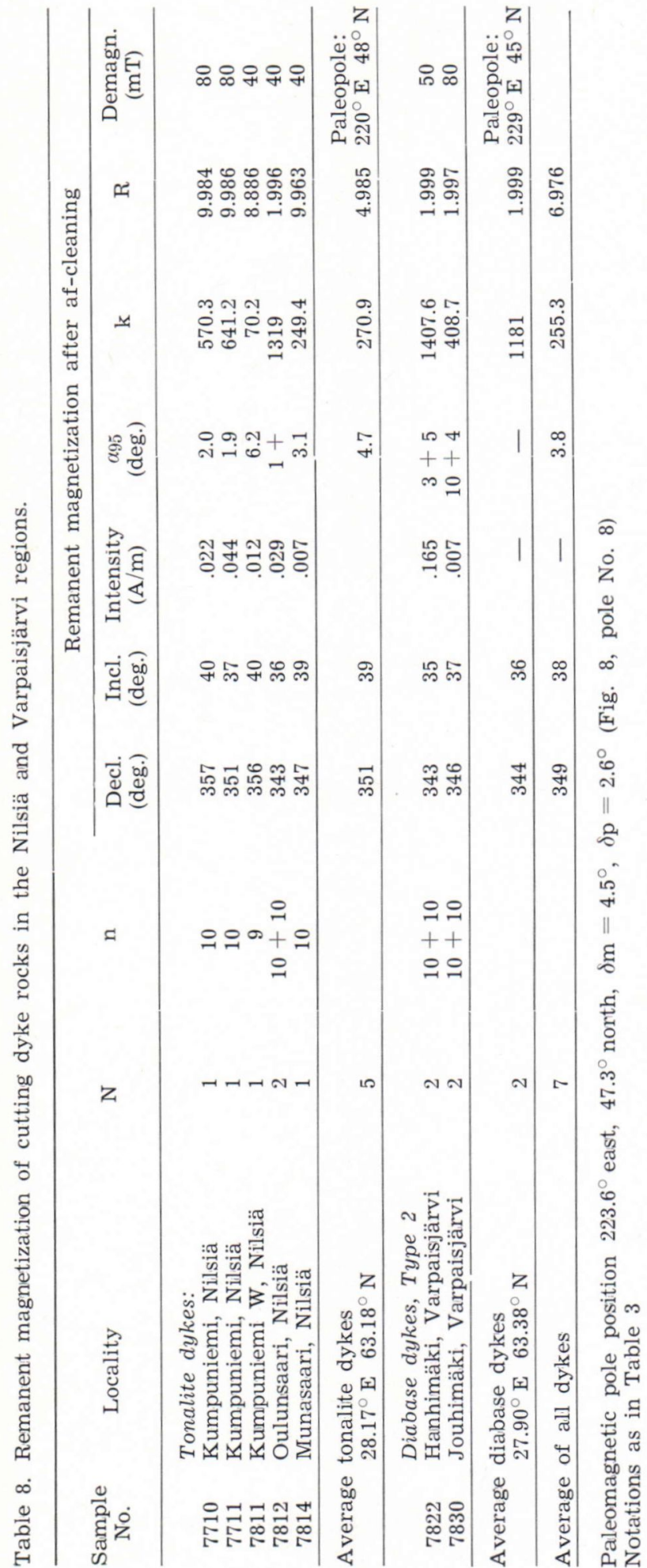

that measured for the subsilicic intrusions in the Haukivesi area (Table 3). As mentioned earlier on p. 114, the magnetization of two of the diabase dykes studied paleomagnetically from Varpaisjärvi differed from that of the others. In these dykes the remanence is parallel to that in the tonalite dykes and is therefore listed with them in Table 8. The corresponding paleomagnetic pole position, $223.6^{\circ} \mathrm{E}$ and $47.3^{\circ} \mathrm{N}$ is given in Fig. 8 as number 8 .

\section{Remanent magnetization of subsilicic rocks in the Iisalmi region}

Hypersthene-bearing subsilicic rocks of an intrusive character occur in the region northeast of the town of Iisalmi near the northeastern boundary of the sulphide ore belt (Fig. 1). Samples for comparison were drilled for paleomagnetic measurements from gabbros, diorites and diabase dykes. The magnetic directions observed in these rocks are given in Table 8 and Fig. 1. There is a rather large scatter in the directions of the remanent magnetization measured. The magnetic orientation in the cutting diabase dikes is slightly different from that in the plutonic gabbros and diorites. Although not verified by radiometric datings, this might be caused by a real difference in the time of emplacement. Paleomagnetic poles 9 and 10 calculated on the basis of the Iisalmi intrusions lay close to the assumed APW path in Fig. 8 but the age difference between the gabbros and diabase dykes has not been asserted.

\section{Discussion}

The geological nature of the sulphide ore belt is not fully understood. It is evident, however, that it differs from its surroundings and must represent a unique part of the crust. This is also seen in the difference in 
Table 9. Remanent magnetization of basic intrusions in the Iisalmi region.

\begin{tabular}{|c|c|c|c|c|c|c|c|c|c|c|c|}
\hline $\begin{array}{l}\text { Sample } \\
\text { No. }\end{array}$ & Rock type & Locality & $\mathrm{N}$ & $\begin{array}{l}\text { Decl. } \\
\text { (deg.) }\end{array}$ & $\begin{array}{l}\text { Incl. } \\
\text { (deg.) }\end{array}$ & $\begin{array}{l}\text { Intensity } \\
(\mathrm{A} / \mathrm{m})\end{array}$ & $\begin{array}{c}\alpha_{95} \\
\text { (deg.) }\end{array}$ & $\mathrm{k}$ & $\mathrm{R}$ & $\begin{array}{l}\text { Demag. } \\
(\mathrm{mT})\end{array}$ & \\
\hline 7339 & $\begin{array}{l}\text { Pyroxene } \\
\text { diorite }\end{array}$ & $\begin{array}{l}\text { Holopanlampi, } \\
\text { Iisalmi }\end{array}$ & 10 & 306 & 50 & 2.554 & 2.4 & 401.0 & 9.978 & 30 & \\
\hline 7340 & $-»-$ & $\begin{array}{l}\text { Tervamäki, } \\
\text { Iisalmi }\end{array}$ & 11 & 305 & 22 & 1.570 & 5.6 & 67.4 & 10.852 & 30 & \\
\hline 7343 & -»- & $\begin{array}{l}\text { Valkiamäki, } \\
\text { Iisalmi }\end{array}$ & 12 & 326 & 46 & 0.535 & 2.5 & 305.8 & 11.964 & 30 & \\
\hline 7344 & Diorite & $\begin{array}{l}\text { Saarela, } \\
\text { Iisalmi }\end{array}$ & 9 & 338 & 39 & 0.142 & 6.3 & 67.4 & 8.881 & 30 & \\
\hline 7345 & $\begin{array}{l}\text { Pyroxene } \\
\text { diorite }\end{array}$ & $\begin{array}{l}\text { Syrjäpuro } \\
\text { Iisalmi }\end{array}$ & 12 & 338 & 29 & 1.390 & 2.5 & 295.9 & 11.963 & 30 & \\
\hline 7767 & Gabbro & $\begin{array}{l}\text { Central prison, } \\
\text { Sukeva }\end{array}$ & 10 & 352 & 26 & 2.779 & 4.6 & 113.1 & 9.920 & 50 & \\
\hline Average & gabbro-dior & $\begin{array}{ll} & \\
27.31^{\circ} \mathrm{E} & 63.62^{\circ} \mathrm{N}\end{array}$ & 6 & 328 & 36 & - & 16.1 & 18.16 & 5.724 & $\begin{array}{l}\text { Pole site } \\
249^{\circ} \mathrm{E} 42^{\circ} \mathrm{N}\end{array}$ & $\begin{array}{l}\text { Pole } 9 \text { in } \\
\text { Fig. } 8\end{array}$ \\
\hline 7772 & Diabase & $\begin{array}{l}\text { Moilanen, } \\
\text { Sonkajärvi }\end{array}$ & 3 & 344 & 66 & .175 & 2.9 & 1786 & 2.998 & 40 & \\
\hline 7773 & Diabase & $\begin{array}{l}\text { Pienimäki, } \\
\text { Sonkajärvi }\end{array}$ & 3 & 345 & 44 & .326 & 3.4 & 1284 & 2.998 & 40 & \\
\hline 7774 & Diabase & $\begin{array}{l}\text { Saarimäki, } \\
\text { Sonkajärvi }\end{array}$ & 3 & 334 & 64 & .222 & 8.7 & 201.0 & 2.990 & 40 & \\
\hline 7775 & Diabase & $\begin{array}{l}\text { Halmemäki, } \\
\text { Sonkajärvi }\end{array}$ & 3 & 334 & 46 & .010 & 9.3 & 176.7 & 2.989 & 100 & \\
\hline Average & diabase dyk & $\begin{array}{l}\text { es } \\
27.50^{\circ} \mathrm{E} \quad 63.73^{\circ} \mathrm{N}\end{array}$ & 4 & 339 & 55 & - & 14.0 & 43.77 & 3.931 & $\begin{array}{l}\text { Pole site } \\
241^{\circ} \mathrm{E} 59^{\circ} \mathrm{N}\end{array}$ & $\begin{array}{l}\text { Pole } 10 \text { in } \\
\text { Fig. } 8\end{array}$ \\
\hline
\end{tabular}

Notations as in Fig. 3 
the paleomagnetic data between the belt area and the region north of it.

The directions of remanent magnetization measured inside the belt vary very little (Fig. 1). This coherency is well seen in the cluster formed by the paleomagnetic poles of the rocks in the belt area (Fig. 8). In contrast to this grouping, the paleomagnetic poles calculated from the data collected in the Varpaisjärvi-Nilsiä and Iisalmi areas are distributed over a wide area (Stars in Fig. 8). Any explanation given for the origin and evolution of the belt has to take this paleomagnetically fundamental difference into consideration.

Three tectonic models that differ in principle have been proposed to explain the origin of the Main Sulphide Ore Belt. As pointed out by several authors (e.g. Gaál and Rauhamäki 1971 and Parkkinen 1975) the large number of transcurrent faults and shear zones testifies to a large lateral displacement along the Belt. The Belt might well have developed as a result of a sequence of lateral displacements and shears. On the other hand, Kahma (1973) and later Bowes (1980) have proposed a tectonic model involving the convergence of two crustal plates with the Belt representing the suture zone of this collision. According to this model, the sulphide-bearing volcanic- sedimentary sequence in the Belt is a remnant of a volcanic island arc system. In the third model, proposed by Marttila (1976) it is suggested that a subsiding rift valley system with a folded and highly metamorphosed volcanogenic-sedimentary pile developed along the axial zone.

The paleomagnetic data available should, in principle, be useful for finding out which of the models proposed are acceptable. If for instance, the Lake-Ladoga - Raahe structure were due mainly to large lateral transcurrent displacements, it would be seen as a difference in the declination and/or inclination of the remanent magnetization on either side of the fault line. Such a difference has not been observed in the paleomagnetic data collected from and north of the Belt area. Furthermore, the type of difference in paleomagnetism between these areas cannot be explained by simple lateral displacement. On the contrary, there must be a fundamental dissimilarity in the geological and thermal history of these two adjuncted areas to be able to produce such a big difference in the nature of the paleomagnetic behaviour as described above and illustrated in Fig. 8.

If the Belt was formed as a result of the convergence of two crustal plates and if the magnetization of these plates took place before the collision, they should show somewhat different orientations in remanence. Hence, they should also show different paleomagnetic pole positions. As discussed by McElhinny and McWilliams (1977), the difference observed is not, however, simply related to the amount of relative motion but also to the geometry of the movement involved. On the other hand, the displacement must be very large to be detected paleomagnetically.

To see convergent plate motion in the paleomagnetic results, we should have paleomagnetic pole data available on both the Archean plate northeast of the Belt and the Presvecokarelian block southwest of it. This is not the case since no such old remnant is known on the southwestern side of the Belt. The divergence in magnetization between the Belt and the basement block in the Varpaisjärvi area north of it cannot be caused by the motion of two approaching plates. Furthermore, the tonalite dykes cutting through the Archean basement in Nilsiä have the same magnetic direction and the same paleomagnetic pole position as do the intrusive rocks of the same age (about $1850 \mathrm{Ma}$ ) within the Belt (Fig. 8). This indicates that no very large lateral displacement has taken place 


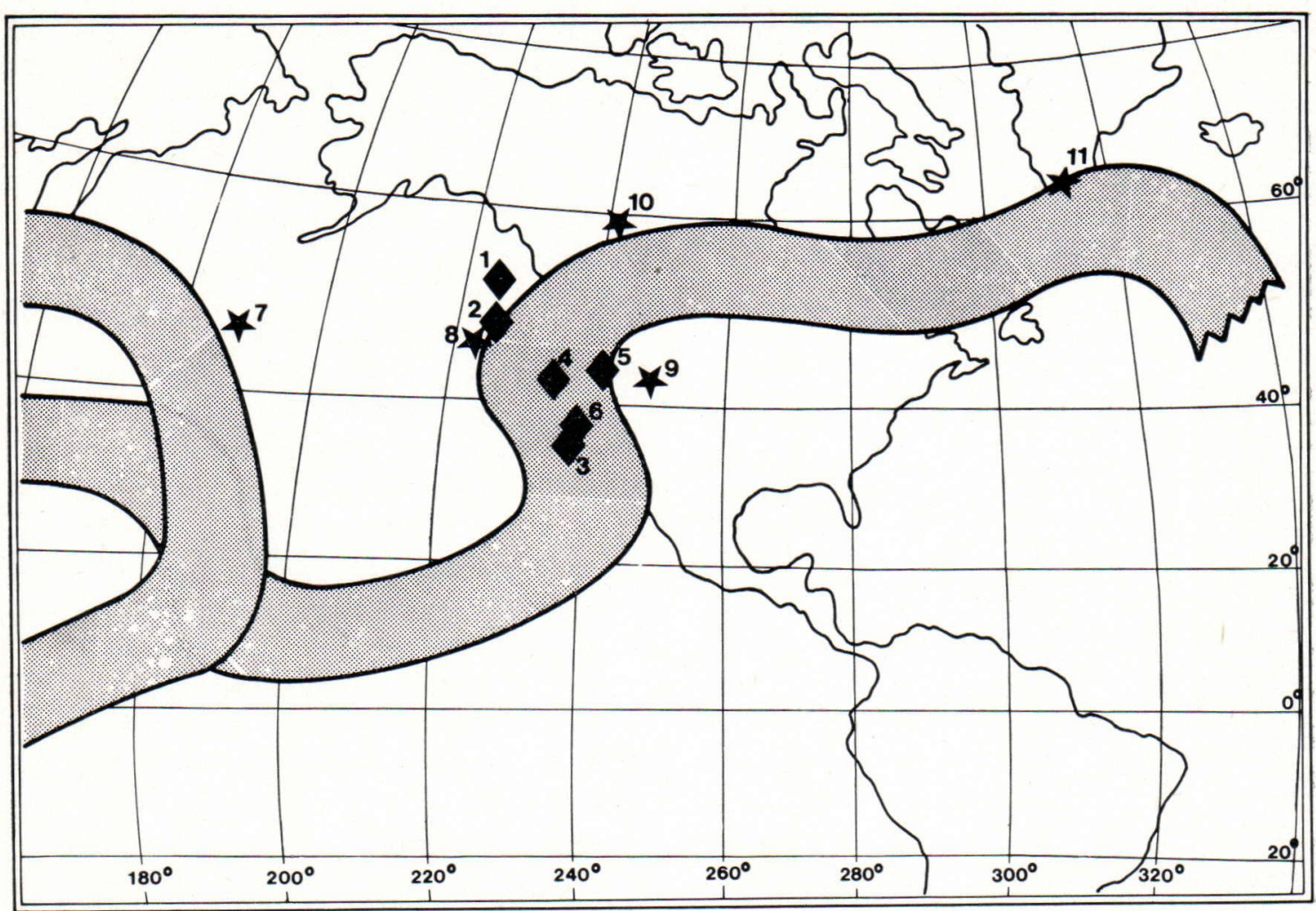

Fig. 8. Paleomagnetic pole positions determined from the Main Sulphide Ore Belt (diamonds) and basement areas north of it in the Varpaisjärvi-Nilsiä and Iisalmi regions (stars) plotted on the apparent paleomagnetic polar wandering path of Pesonen and Neuvonen (1981). Pole No 1. Subsilicic intrusions in the Haukivesi area, Table 3. No 2. Lamprophyre dykes in the Haukivesi area, Table 3. No 3. Subsilicic intrusions in the Pielavesi area, Pesonen and Neuvonen (1981). No 4. Subsilicic intrusions in the Pielavesi-Kiuruvesi area, Table 4. No 5. Ylivieska gabbros (Pesonen and Stigzelius 1972). No 6. Pohjanmaa gabbros (Pesonen and Stigzelius 1972). No 7. Type 1 diabase dykes in Varpaisjärvi, Table 6. No 8. Type 2 tonalite dykes and diabase dykes, in the Nilsiä-Varpaisjärvi area, Table 8. No 9. Gabbros in the Iisalmi area, Table 9. No 10. Diabase dykes from Iisalmi area. Table 9. No 11 . Hypersthenebearing isolated basement complex in the Varpaisjärvi area, Table 5.

between the Belt and the Archean craton area since Svecokarelian time.

The simplest tectonic model to explain the observed paleomagnetic character of the areas now studied is axial uplift or subsiding of the Belt in relation to the basement complex in the northeast. The homogeneous and coherent remanence measured on the erosion surface in the Belt area could have been created in the rocks of the rising Belt in a manner similar to that described by Beckman et al. (1977) and Morgan (1976) from Greenland (see also Ueno and Irving 1976). The coherent magnetization would have taken place when the rock units passed the blocking or Curie-temperature in the crust (zero-line of Neuvonen 1961).

If however, this type of uplift magnetization takes place in rock units that are of similar age but belonging to two adjacent blocks with a different rate of uplift, the rocks should show different magnetic directions on the erosion surface. The tonalite dykes in Nilsiä (Table 8) and possibly also the subsilicic intrusions in Iisalmi (Table 9) have the same age as the intrusive rocks in the Belt 
area. The paleomagnetic directions are also similar, and the paleomagnetic pole positions for all these rocks (poles 8, 9 and 10 and all the diamond-poles) plot in the same area in Fig. 8. This has important consequences for the interpretation of the paleomagnetic results obtained.

As the first conclusion we can postulate that the paleomagnetic measurements in the area date the very same events as do the radiometric $\mathrm{U}-\mathrm{Pb}$ age determinations. This is a very important fact since many Svecokarelian intrusive in this same area (about $220^{\circ}-250^{\circ} \mathrm{E}$ and $30^{\circ}-60^{\circ} \mathrm{N}$ ) rocks in other localities of the Fennoscandian Shield (Pesonen and Neuvonen 1981), plot for example intrusive rocks in northern Sweden (Cornwell 1968), subsilicic plutonites in SW Finland (Neuvonen 1974) and effusive and dyke rocks in Soviet Karelia (McElhinny and Cowley 1977). All these rocks are about or slightly younger than $1900 \mathrm{Ma}$. Therefore, there is every reason to consider this spot as one of the Key Points of the APW curve of the Fennoscandian Shield.

Because the pole positions of the tonalite dykes and the Iisalmi intrusion are similar to those of the Belt rock, the homogeneity observed in the magnetization within the Belt is not likely to have been caused by any plate motion, whether vertical or horizontal. Any such movement would have been recorded on these rocks and would have resulted in a difference in the magnetic directions. Furthermore, there has evidently not been any marked crustal uplift associated with the belt since Svecokarelian time, since such a phenomenon would certainly have been recorded in the magnetization of the Belt rocks. It is also evident that the age of magnetization of the Belt does not accord with the fission track ages measured by Lehtovaara (1976).
The radiometric age data derived from the Belt area indicate a short period of igneous activity about $1880-1840 \mathrm{Ma}$ ago.

This period is also recorded in the magnetization of the rocks of the Belt and is illustrated as a clustering of the paleomagnetic poles in Fig. 8. Although the convergence of two crustal plates cannot explain the magnetization observed in the area studied, high-temperature metamorphism and the intensive igneous activity associated with it might well be caused by plate suturing. On the other hand, the high heat flow and high temperature metamorphism connected with magmatic activity along the Belt can well explain both the paleomagnetic and the radiometric data without any suturing. As proposed by Bowes (1980) plate collision and the associated subduction associated, would, however, nicely complete the whole evolution picture of the Main Sulphide Ore Belt. This model would explain the volcanogenic-sedimentary pile and the associated sulphide ores as the remnant of a volcanic island arc system. The same explanation was earlier adopted by Kahma (1973). An even more precise explanation for the ore deposits of the Belt would, however, be that of deep fluid convection as described e.g. Hutchinson et al. (1980).

The paleomagnetic pole position calculated for type 1 diabase dykes in Varpaisjärvi (pole number 7 in Fig. 8) lies far off the adopted APW curve. The Archean basement block intersected by these dykes was evidently in an isolated position during the Proterozoic time, since the high grade Archean mineral parageneses are preserved and the paleomagnetic directions are still measurable. The positive baked contact test (p. 124) indicates that the magnetic directions measured for both the basement and the cutting dykes are primary. As proposed by Pesonen and Neuvonen (1981) a more complex polar wandering curve with a large post-orogenic loop could 
be drawn for the age interval $1850-1750 \mathrm{Ma}$ to fit this diabase pole as well. On the other hand, as mentioned earlier (p. 115), field evidence suggests that these diabase dikes are more readily correlated with the Jatulian dykes about $2150 \mathrm{Ma}$ old. Therefore, discussion on the shape of the APW curve must be postponed until more paleomagnetic work has been done on new, radiometrically dated rocks aged between 1900 and $2500 \mathrm{Ma}$.

\section{References}

Aho, L. (1979) Petrogenetic and geochronological studies of metavolcanic rocks and associated granitoids in the Pihtipudas area, central Finland. Comm. Géol. Finlande Bull. 300, 21 pp.

Beckmann, G. E. J., Olesen, N. Ø. and Sørensen, K. (1977) A paleomagnetic experiment on crustal uplift in west Greenland. Earth and Planet. Sci. Lett., 269-279.

Bowes, D. R. (1980) Correlation in the Svecokarelides and a crustal model in principles and criteria of subdivision of Precambrian in mobile zones. Mitrofanov, F.P. ed. Nauka, Leningrad.

Cornwell, J. D. (1968) The magnetization of Precambrian rocks from the Tärendö district, North Sweden. Geol. Fören. Stockh. Förh. 90, $529-536$.

Doe, B. R. and Zartman, R. E. (1979) Chap. 2, Plumbotectonics I, The Phanerozoic. In Barnes, H.L., ed. Geochemistry of ore deposits, New York, John Wiley and Sons.

Everitt, C. W. F. and Clegg, J. A. (1962) A field test of paleomagnetic stability. Geoph. J.R. Astr. Soc. 6, 312-319.

Foster, J. H. (1966) A paleomagnetic spinner magnetometer using a fluxgate gradiometer. Earth and Planet. Sci. Lett. 1, 463-466.

Gaál, G. and Rauhamäki, E. (1971) Petrological and structural analysis of the Haukivesi area between Varkaus and Savonlinna, Finland. Bull. Geol. Soc. Finland 43 (2) 265-337.

- , Helovuori, O., Huhma, A., Marttila, E., Parkkinen, J., Pehkonen, E., Saastamoinen, J. and Viluksela, E. (1973) On the stratigraphy of Ostrobothnia, Savo and North Karelia, Finland. XI Nordiska geologiska vintermötet Oulu/Uleåborg 1974 Januari 3-5, B. Abstr. 59-60.
Acknowledgements - The authors are indebted to many persons who helped them during their work in the field and in the laboratory. Special thanks are due to Mrs. Ritva Ääri for the magnetic measurements, to Mrs. Hanna Koskinen for most of the drawing, to Mrs. Tuula Wan for typing the manuscript and to Dr. Lauri Pesonen for critically reading and correcting it.

The assistance given by the National Research Council for Science towards collecting the samples studied paleomagnetically is gratefully acknowledged.

Gaál, Gabor (1980) Geological setting and intrusion tectonics of the Kotalahti nickel-copper deposit, Finland. Bull. Geol. Soc. Finland 52, 101-128.

Hackman, V. (1914) Über Camptonitgänge im Mittleren Finnland, Bull. Comm. géol. Finlande 42.

- (1933) Kivilajikartan selitys. Lehti D2 Savonlinna. Suomen geologinen yleiskartta (General Geological Map of Finland), 1-175.

Helovuori, O. (1979) Geology of the Pyhäsalmi ore deposit, Finland. Econ. Geol. 74, 1084-1101.

Honkasalo, T. (1962) Gravity survey of Finland in the years 1945-1960. Publ. of Geod. Inst. No $55,32 \mathrm{pp}$. and 3 maps.

Huhma, A. (1975) Suomen geologinen kartta $1: 100000$, Kallioperäkartan selitys, lehti 4311 Sivakkavaara.

- (1981) Youngest Pre-Cambrian dyke rocks in North Karelia, eastern Finland, Bull. Geol. Soc. Finland 53-2, 67-82.

Hutchinson, R. W., Fyfe, W. S., and Kerrich, R. (1980) Deep fluid penetration and ore deposition. Miner. Sci. Eng. 12, 3, 107-120.

Härme, M. (1961) On the fault lines in Finland. Bull. Comm. géol. Finlande 196, 437-444.

Kahma, A. (1973) The main metallogenic features of Finland. Geol. Surv. Finland, Bull. 265, $28 \mathrm{pp}$.

Kauppinen, H. (1973) Iisalmen alueen lohkorakenteista. Unpub. manuser. Univ. of Turku, $102 \mathrm{pp}$.

Korsman, K. and Lehijärvi, M. (1973) Kallioperäkartan selitys, Lehti 3144, Sulkava. Summary: Precambrian rocks of the Sulkava map-sheet area. Geological Map of Finland, 1:100000. 24 pp. 
- and Pääjärvi, A. (1980) Geological Map of Finland, Sheet 3234, Varkaus, 1:100 000.

Kouvo, O. and Kulp, J. L. (1961) Isotopic composition of Finnish galenas. New York Acad. Sci. Ann. 91, 476-491.

Laukkanen, J. (1982) Rantasalmen lamprofyyrijuonet ja niiden mineralogia. M. Sci. thesis, Univ. of Turku (in prep.).

Lehtovaara, J. (1976) Apatite fission track dating of Finnish Precambrian intrusives. Ann. Acad. Sci. Fennicae A III, 117.

Marttila, E. (1976) Evolution of the Precambrian volcanic complex in the Kiuruvesi area, Finland Geol. Surv. Finland. 283, 109 p.

- (1981) Geological map of Finland 1:100000. Explanation to the maps of Pre-Quaternary rocks. Sheet 3323 Kiuruvesi.

McElhinny, M. W. and Cowley, J. A. (editors) (1977) Paleomagnetic research from the U.S.S.R. Aust. Natl. Univ., Res. Sch. of Earth Sci., RSES Publ. no 1268.

- and McWilliams, M. O. (1977) Precambrian geodynamics - a paleomagnetic view. Tectonophysics 40, 137-159.

Meriläinen, K. (1976) The granulite complex and the adjacent rocks in Lapland, northern Finland. Geol. Surv. Finland. Bull. 281. 129 p.

Mikkola, A. K. and Niini, H. (1968) Structural position of ore-bearing areas in Finland, Bull. Geol. Soc. Finland 40, 17-33.

Mrorgan, G. E. (1976) Paleomagnetism of a slowly cooled plutonic terrain in western Greenland. Nature 259, 382-385.

Neuvonen, K. J. (1961) The apparent age pattern of the crust. Bull. Comm. géol. Finlande 196, $445-454$.

- (1970) Paleomagnetism of the dike systems in Finland V. Remanent magnetization of the Ãva instrusives. Bull. Geol. Soc. Finland 42, 101107.

- (1974) Paleolatitude and cause of the Svecokarelian orogeny. Bull. Geol. Soc. Finland, 46, $75-79$.

Nykünen, O. (in prep.) Explanation to the maps of Pre-Quaternary rocks. Geological map of Finland 1: 100000 , sheets $4124+4142$ Punkaharju and $4123+4114$ Simpele.

Paarma, H. and Marmo, V. (1961) Eräistä suurrakenteista Suomen geologiaan sovellettuina. Summary: On some large structures with application into geology of Finland. Terra 73, $78-86$
Paavola, J. (1976) On the metamorphism of the Haukivesi area. Bull. Geol. Soc. Finland 48, $1-3$.

Parkkinen, J. (1975) Deformation analysis of a Precambrian mafic intrusive: Haukivesi-area, Finland. Geol. Surv. Finland, Bull. 278.

Penttilä, E. (1963) Some remarks on the earthquakes in Finland. Fennia 89, 25-28.

Pesonen, L. J. and Stigzelius, E. (1972) On petrophysical and paleomagnetic investigations of the gabbros of the Pohjanmaa region, MiddleWest, Finland. Geol. Surv. Finland, Bull. 260, $27 \mathrm{pp}$.

- (1973) On the magnetic properties and paleomagnetism of some Archean volcanic rocks from the Kirkland Lake area.

- (1978) Paleomagnetic, paleointensity and paleosecular variation studies of Keweenawan igneous and baked contact rocks. Unpubl. Ph.D. thesis, Univ. of Toronto, $375 \mathrm{pp}$.

- and Neuvonen, K. J. (1981) Paleomagnetism of the Baltic Shield - Implications for Precambrian tectonics. In: Pre-Cambrian Plate Tectonics, A. Kröner (ed.) Elsevier, Amsterdam, Chapter 25.

Rouhunkoski, P. (1968) On the geology and geochemistry of the Vihanti zinc ore deposit, Finland. Comm. géol. Finlande Bull. 236, 121 pp.

Talvitie, J. (1971) Seismotectonics of the Kuopio region, Finland. Bull. Comm. géol. Finlande 248, 41 pp.

Salli, I. (1965) Kallioperäkartan selitykset, 24322434, Pyhäjoki-Vihanti. Summary: Explanation to the map of rocks, Geological map of Finland, $1: 100000$, sheets 2432-2434, 51 pp.

Stacey, J. S., Doe, B. R., Silver, L. T. and Zartman, R. E. (1977) Plumbotectonics IIA, Precambrian massive sulfide deposits. In: Geochronology and problems of the metallogeny. Nauka, Moscow, 93-106 (In Russian).

Streckeisen, A. (1975) To each plutonic rock its proper name, Earth-Sci. Rev. 12, 1-33.

Ueno, H. and Irving, E. (1976) Paleomagnetism of the Chibougamau greenstone belt, Quebeck, and the effects of Grenvillian post-orogenic uplift. Precambrian Res., 3, 303-315.

Vaasjoki, M. (1977) Rapakivi granites and other postorogenic rocks in Finland: their age and the lead isotopic composition of certain associated galena mineralizations. Geol. Surv. Finland. Bull. 294. 66 pp.

- (1981) The lead isotopic composition of some Finnish galenas. Geol. Surv. Finland. Bull. 316. Wasserburg, G. J. (1963) Diffusion process in lead- 
uranium systems. J. Geophys. Res. 68, 48234846.

Wetherill, G. W., Kouvo O. and Tilton, G. R. (1962) Age measurements on rocks from the Finnish precambrian. J. Geol. 70, 74-88.

Wilkman, W. W. (1924) Om diabasgångar i mellersta Finland, Bull. Comm. géol. Finlande 71, 35 pp.
- (1938) Suomen geologinen yleiskartta, lehti C3, Kuopio, Kivilajikartan selitys, Suomen geologinen toimikunta. General geological map of Finland, 1:400 000, Sheet C3.

York, D. (1966) Least-squares fitting of a straight line. Canadian J. Phys. 44, 1079-1089.

Manuscript received, July 27, 1981. 